\title{
PENGEMBANGAN KIT MEDIA PEMBELAJARAN IPA BERBASIS SAINTIFIK UNTUK MENINGKATKAN PENGUASAAN KONSEP MATERI TATA SURYA PADA SISWA KELAS VI SD
}

\author{
Kahfi Rahmah ${ }^{1}$, Wahono Widodo ${ }^{2}$, Imam Supardi ${ }^{3}$ \\ ${ }^{1}$ Mahasiswa Program Pascasarjana, Prodi Pendidikan Dasar, Universitas Negeri Surabaya, \\ ${ }^{2 \& 3}$ Dosen Pascasarjana, Prodi Pendidikan Dasar, Universitas Negeri Surabaya \\ e-mail:kahfi_rahmah@yahoo.com
}

\section{Received : November 2018}

Reviewed : Desember 2018

Accepted : Januari 2019

Published : Januari 2019

\section{ABSTRACT}

This research aims to produce Media Kit Science Learning Based on Scientific Method that feasible to improve mastery of concept on the material of Solar System in Grade $6^{\text {th }}$ elementary school. This reaserch is a developmental reasearch, wich model reasearch is ADDIE. Limited try out design using one group pretest-posttest design with quantitative descriptive analysis techniques and descriptive qualitative. The try out subject that used in this reaserch are students Grade $6^{\text {th }}$ of Elementary School 3 Kedungwinangun, Kebumen, academic year 2015/2016 on the material of Solar System. The result of reaserch showed: (1) The all content of the lesson plan, such RPP, BAS, LKS, Media KIT about Solar System, and Learning Aspects of Knowledge Test Results are feasible; level of legibility BAS and LKS categorized well; (2) Development content of lesson plans is practice to used, shown by implementation of content of lessonplan up to 100\%; (3) The lesson is effective, achievement learning objectives and indicators is shown by all of students can reach the completeness criteria; The students activity is studen centered, average of students activity about observed is $84,67 \%$, 65,33\% for questioning, 84,5\% for collecting information, $83,17 \%$ for associating information, and $100 \%$ for communicating; result study of students shown there is increasing mastery of concept on the solar system material with categorie of gain scor is high. Based on the result and discussion of this study concluded that the device of science learning based on scientific method that use media kit of solar system feasible, practice, and effective for use in study.

Key Words: Kit Media, Science Learning, Scientific, dan Mastery of Concept.

\section{ABSTRAK}

Penelitian ini bertujuan untuk menghasilkan Kit Media Pembelajaran IPA berbasis saintifik yang layak digunakan untuk meningkatkan penguasaan konsep materi tata surya pada siswa kelas VI SD. Penelitian ini merupakan penelitian pengembangan, dengan model ADDIE. Desain uji coba terbatas menggunakan one group pretestposttest design dengan teknik analisis deskriptif kuantitatif dan deskriptif kualitatif. Subjek ujicoba ini adalah siswa kelas VI SDN 3 Kedungwinangun, Kebumen, tahun pelajaran 2015/2016 dengan materi tata surya. Hasil penelitian menunjukkan: (1) Perangkat pembelajaran yang meliputi RPP, LKS, BAS, Kit Media Tata Surya, Tes Penguasaan Konsep valid; tingkat keterbacaan BAS dan LKS berkategori baik; (2) Perangkat pembelajaran yang telah dikembangkan praktis digunakan, ditunjukkan dengan terlaksananya kegiatan pembelajaran dengan persentase keterlaksanaan sebesar 100\%; (3) Pembelajaran berlangsung efektif, pencapaian tujuan pembelajaran dan indikator ditunjukkan dengan tercapainya kriteria ketuntasan sebesar $100 \%$ dari jumlah siswa, aktivitas siswa dalam pembelajaran lebih dominan yang ditunjukkan dengan rata-rata aktivitas siswa untuk kegiatan mengamati sebesar 84,67\%, menanya sebesar 65,33\%, mengumpulkan informasi 84,5\%, mengolah informasi 83,17\%, dan mengkomunikasikan 100\%; hasil belajar siswa 
menunjukkan adanya peningkatan penguasaan konsep siswa mengenai materi tata surya meningkat dengan kategori gain skor tinggi. Berdasarkan hasil dan diskusi penelitian dapat disimpulkan bahwa perangkat pembelajaran IPA berbasis saintifik yang menggunakan Kit Media IPA Tata Surya valid, praktis, dan efektif untuk digunakan dalam pembelajaran.

Kata Kunci: Kit Media, Pembelajaran IPA, Saintifik, dan Penguasaan Konsep.

\section{PENDAHULUAN}

Pendidikan merupakan sarana bagi manusia untuk mengembangkan diri, menambah wawasan, menggali potensi diri, baik potensi akademik maupun keterampilan. Pendidikan berpengaruh besar terhadap kualitas sumber daya manusia suatu negara. Hal ini sesuai pernyataan Dewantara (1977:3) bahwa sistem pendidikan akan berfaedah bagi kehidupan berbangsa karena kekuatan dan kepandaian yang dimiliki oleh suatu bangsa merupakan kekuatan dari tiap-tiap individu yang dapat berguna untuk kemakmuran negeri.

Sistem pendidikan memengaruhi sistem pengajaran. Dari keseluruhan proses pendidikan, belajar merupakan kegiatan yang paling pokok, berhasil atau tidaknya pencapaian tujuan pendidikan tergantung pada proses belajar mengajar yang baik (Slameto, 2010:1).

Dalam hal ini, pembelajaran bukan hanya sebatas interaksi antara guru dengan siswa tetapi juga proses interaksi itu sendiri. Guru hendaknya bertindak sebagai bagian dari kelas pembelajaran yang antara lain mempresentasikan informasi berupa pengetahuan, fakta, dan konsep kepada siswa serta mencontohkan keterampilan tertentu secara jelas dan efisien dalam pembelajaran (Arends, 2008: 45).

Dari beberapa disiplin ilmu yang ada, Ilmu Pengetahuan Alam merupakan salah satu mata pelajaran yang sebagian besar konten materinya tentang peristiwa dan gejala-gejala alam yang memungkinkan bagi siswa untuk memperoleh pengetahuan dan keterampilan. Pengetahuan, keterampilan, gagasan-gagasan, dan konsepkonsep yang dipelajari siswa terorganisasi dengan alam sekitar dapat diperoleh dari pengalaman melalui serangkaian proses ilmiah, antara lain penyelidikan, penyusunan, dan penyajian gagasan-gagasan (Subiyanto, 1988:47).

KTSP mengamanatkan esensi pendekatan keterampilan proses dalam pembelajaran yang dapat dipadankan dengan suatu proses ilmiah. Mata pelajaran ilmu pengetahuan dan teknologi untuk jenjang SD/MI/SDLB dimaksudkan untuk mengenal, menyikapi, dan mengapresiasi ilmu pengetahuan dan teknologi, serta menanamkan kebiasaan berpikir dan berperilaku ilmiah yang kritis, kreatif, dan mandiri (Karsidi, 2007:7). Dengan proses ilmiah, siswa akan lebih menikmati proses pembelajaran yang aktif, kreatif, dan menyenangkan serta bermakna tanpa terpaku dengan hafalan-hafalan tentang materi yang monoton.

Hal ini sesuai dengan prinsip-prinsip pengembangan Kurikulum Tingkat Satuan Pendidikan (KTSP) yakni berpusat pada potensi, perkembangan, kebutuhan, dan kepentingan peserta didik, bahwa peserta didik memiliki posisi sentral (berpusat pada siswa) untuk mengembangkan kompetensinya (Rohman, 2012:113).

Tahapan-tahapan pendekatan ilmiah seperti mengamati, mengukur, mengelompokkan, dan sebagainya saat ini lebih dikenal dengan pendekatan saintifik (mengamati, menanya, mengumpulkan informasi, mengolah informasi, dan mengkomunikasikan). Pendekatan saintifik tidak hanya menyampaikan penemuan-penemuan ilmiah tetapi mengarahkan pada penalaran yang tepat dan dibutuhkan untuk memecahkan suatu masalah dalam kehidupan sehari-hari (Nagl, Obadovic, \& Segedinac, 2012). Dengan demikian, pembelajaran yang menggunakan pendekatan saintifik membantu melatihkan siswa berbagai keterampilan dalam memperoleh pengetahuan.

Untuk menyelenggarakan kegiatan pembelajaran yang efektif, tidak cukup hanya dengan strategi pembelajaran yang baik, namun juga didukung dengan sarana pembelajaran yang baik pula. Heinich dan kawankawan (1982) mengemukakan bahwa pemakaian media belajar dapat membangkitkan keinginan dan minat yang baru bagi siswa serta membangkitkan motivasi belajar. Serta diharapkan dapat memacu proses dan hasil belajar siswa dengan kondisi dinamis, kreatif dan relevan dengan kehidupan sehari-hari.

Berbanding terbalik dengan harapan di atas, di SDN 3 Kedungwinangun, peneliti menemukan pembelajaran masih didominasi oleh guru dengan metode ceramah sehingga siswa cenderung pasif. Kurangnya pemahaman siswa juga ditunjukkan dengan rendahnya nilai sebagian besar siswa yang belum tuntas $(\mathrm{KKM} \geq 70)$ Sarana mengajar di sekolah tersebut juga sangat minim, terutama media alat peraga untuk mata pelajaran IPA yang berkaitan dengan alam semesta seperti materi tata surya belum ada 
sehingga cara untuk memperoleh pengetahuan melalui serangkaian keterampilan proses ilmiah dalam kegiatan pembelajaran belum terlihat.

Media atau alat peraga pada sekolah umumnya yang sering ditemui adalah media audio visual berupa VCD pembelajaran yang ringkas, fleksibel, dan murah, namun penggunaannya membutuhkan alat kelengkapan lain. Berbeda dengan VCD pembelajaran, kit media mendukung pembelajaran yang berpusat pada siswa karena kit dapat memberikan pengalaman belajar yang lebih konkret, menumbuhkan kemampuan kerja sama, komunikatif, serta dapat menginterpretasikan suatu peristiwa/ kejadian.

Kit media IPA khususnya materi Tata Surya yang ada pada sekolah-sekolah umumnya berupa seperangkat yang terdiri dari macam-macam model matahari dan planet-planet beserta alat pendukung lainnya dan dilengkapi buku petunjuk penggunaan. Kelebihannya antara lain dapat memberikan gambaran subjek yang tidak mungkin didatangkan secara langsung sehingga dapat membantu mengatasi keterbatasan pengamatan, ruang dan waktu. Adapun kekurangan dari kit media antara lain perlu untuk merakitnya terlebih dahulu sebelum melakukan percobaan sehingga perlu untuk mengetahui dan memahami cara mengoperasikannya dengan benar.

Berdasarkan uraian di atas, peneliti merasa perlu untuk mengadakan perbaikan pada pembelajaran dan sarana berupa media pembelajaran. Dalam hal ini peneliti mencoba mengembangkan kit media pembelajaran IPA berbasis saintifik yang dirancang khusus untuk memudahkan siswa dalam memahami konsep materi ajar dengan mengajukan judul "Pengembangan Kit Media Pembelajaran IPA Berbasis Saintifik untuk Meningkatkan Penguasaan Konsep Materi Tata Surya pada Siswa Kelas VI SD”.

\section{KAJIAN PUSTAKA}

\section{A. Hakikat IPA}

Ibrahim (2008:6) mendefinisikan IPA sebagai produk ilmiah (fakta, informasi, konsep, teori, prinsip, hukum, serta prosedur-prosedur yang terdapat di dalam IPA), proses ilmiah, dan sikap ilmiah. Selanjutnya dalam buku yang lain, Ibrahim (2010:1) mengemukakan sains adalah studi sistematik tentang alam dan bagaimana alam itu mempengaruhi kehidupan dan lingkungan kita. Hal ini berarti pada pembelajara IPA, proses bagaimana memperoleh pengetahuan sangat penting agar siswa dapat dengan baik dan benar memperoleh produk ilmiah serta memperoleh keterampilan-keterampilan-keterampilan sains dalam proses memperoleh pengetahuan.
Untuk menemukan dan menerapkan pengetahuan ilmiah serta menerapkan sains, studi dan praktiknya melibatkan tiga elemen utama yakni sikap (scientific attitude), proses atau metode (scientific process), dan produk (scientific product) (Ibrahim, 2010:3) seperti yang diperlihatkan pada bagan berikut.

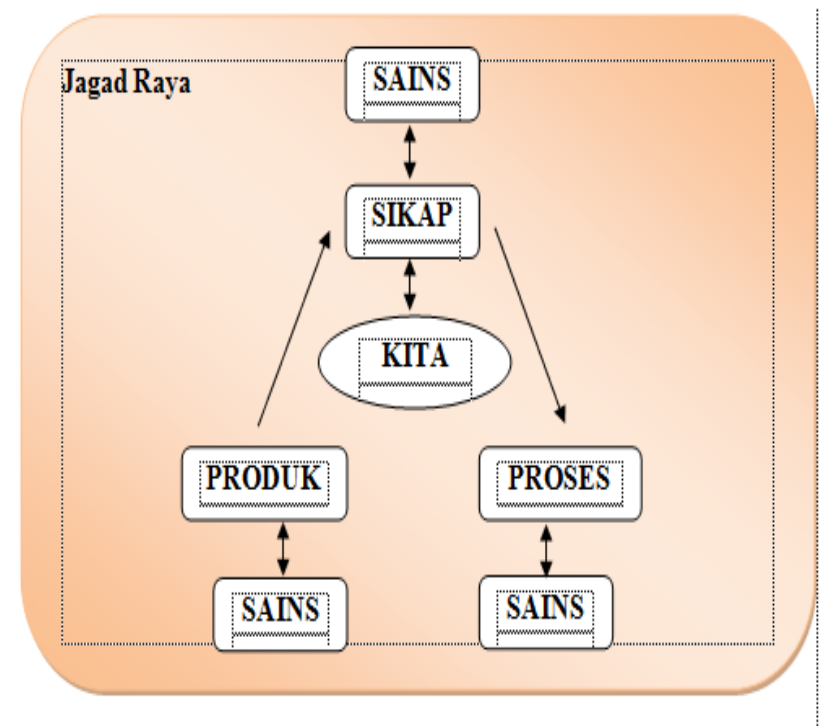

Sumber:Ibrahim (2010:3)

Gambar 1.

Tiga Elemen Praktik Sains

Berdasarkan penjelasan di atas peneliti menyimpulkan bahwa ilmu pengetahuan alam merupakan kumpulan pengetahuan yang didapat dari hasil kegiatan manusia melalui proses ilmiah dan sikap ilmiah secara teratur, sistematis, berobjek, dan bermetode serta menghasilkan produk ilmiah yang aplikatif dalam kehidupan sehari-hari.

\section{B. Pembelajaran IPA}

Permendikbud No. 103 Tahun 2014 tentang Pembelajaran Pendidikan Dasar dan Pendidikan Menengah, menyatakan bahwa prinsip pembelajaran yang dilaksanakan ialah dari peserta didik "diberi tahu" menuju peserta didik "mencari tahu", dari guru sebagai satusatunya sumber belajar menjadi belajar berbasis aneka sumber belajar, dan dari pendekatan kontekstual menuju proses sebagai penguatan penggunaan pendekatan ilmiah. Dengan menggunakan pendekatan ilmiah, siswa akan mampu menemukan dan mengembangkan sendiri fakta dan konsep serta menumbuhkan dan mengembangkan sikap dan nilai (Sujarwanta, 2012:75).

Nur (dalam Ibrahim, 2010:3) mengemukakan metode ilmiah adalah metode untuk mendapatkan pengetahuan lewat dua jalur, yaitu jalur akal (nalar) dan jalur pengamatan. Wujud operasional metode ilmiah adalah 
penyelidikan ilmiah. Ciri khas metode ilmiah adalah pemecahan masalah melalui penalaran dan pengamatan (Ibrahim, 2010:4-21) beberapa di antaranya adalah sebagai berikut:

1. Pengamatan (observasi)

Pengamatan dalam hal ini bukan hanya sekedar melihat atau mendengar saja namun merupakan keterampilan proses dasar dalam sains. Dari kegiatan mengamati yang diharapkan adalah muncul rasa ingin tahu pada diri siswa. Dengan mengamati pula, akan merangsang siswa untuk berpikir ke arah yang lebih komplek lagi. Kesesuaian dan keakuratan data didasarkan pada pengamatan yang baik, sehingga kesimpulan yang dihasilkan juga memiliki tingkat keakuratan tinggi.

Observasi dilakukan menggunakan alat indera, antara lain indera penglihat (mata), indera pendengar (telinga), indera peraba dan perasa (kulit), indera pembau (hidung), dan indera pengecap (lidah). Keterampilan dalam mengamati merupakan keterampilan yang sangat penting untuk mengembangkan keterampilan-keterampilan yang lain seperti keterampilan memprediksi, menafsirkan, mengkomunikasikan, dan sebagainya seperti diperlihatkan pada bagan berikut ini.

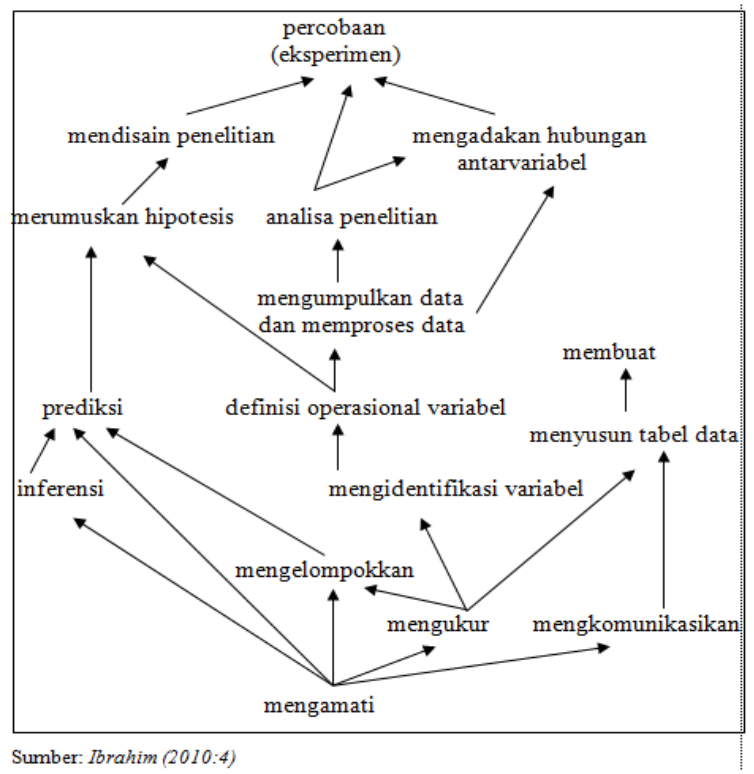

Gambar 2.

Keterampilan Mengamati

Klasifikasi/ penggolongan merupakan proses menyusun benda atau kejadian dengan mengamati persamaan, perbedaan, untuk kemudian dikelompokkan berdasarkan tujuan tertentu. Dalam ilmu pengetahuan, klasifikasi memudahkan dalam menyederhanakan materi pelajaran sehingga mudah untuk dipelajari serta memudahkan untuk menyusun pola pengetahuan yang didapatkan.

2. Komunikasi

Keterampilan komunikasi dapat dilakukan dengan cara mendeskripsikan ciri-ciri suatu objek, merangkum informasi dari teks, menjelaskan data berupa grafik/tabel, menyajikan data dalam bentuk grafik/tabel, menjelaskan hasil pengamatan, menggabungkan data hasil kelompok, dan sebagainya.

3. Bertanya

Pertanyaan merupakan alat untuk merencanakan, mengajar, berpikir, dan belajar. Dalam sains pertanyaan siswa berperan penting dalam pembelajaran mereka. Peningkatan mutu pertanyaan mendukung peningkatan pembelajaran bagi siswa.

4. Keterampilan menafsirkan dan prediksi

Proses pemikiran yang digunakan untuk membuat prediksi menjadi dasar untuk mengadakan penyelidikan berupa eksperimen. Sedangkan tafsiran adalah suatu penjelasan atau interpretasi dari hasil pengamatan yang berdasarkan pada suatu peristiwa atau keadaan.

5. Keterampilan proses terpadu: eksperimen

Merencanakan dan melakukan ekperimen merupakan keterampilan proses terpadu yang melibatkan berbagai keterampilan proses dasar seperti pengamatan, pengukuran, klasifikasi, komunikasi, bertanya, dan sebagainya. Dalam menemukan konsep-konsep dan prinsip-prinsip sains, eksperimen dapat didefinisikan sebagai usaha sistematik yang direncanakan untuk menghasilkan data dalam rangka menjawab suatu masalah atau menguji suatu hipotesis.

Berdasarkan uraian di atas, dapat peneliti simpulkan bahwa pembelajaran IPA adalah serangkaian kegiatan yang didasarkan pada metode ilmiah yang mencakup penalaran dan pengamatan suatu penyelidikan dalam proses memperoleh produk ilmiah (fakta, konsep, prinsip, hukum) yang terkait dengan pengetahuan alam.

\section{Media}

Fathurrohman (2009:65) mengemukakan media ialah sesuatu yang dapat membawa informasi dan pengetahuan dalam interaksi yang berlangsung antara pendidik dan peserta didik. Sedangkan Smaldino, dkk. (2011:7) dan Heinich (1982:8) mengemukakakan "medium is anything that carries information between a source and a receiver" yang berarti media adalah istilah yang merujuk pada apa saja yang membawa informasi antara sebuah 
sumber dan sebuah penerima yang bertujuan untuk memudahkan komunikasi dalam belajar. Media juga diartikan sebagai sarana fisik yang berisi pesan atau sarana untuk menyampaikan pesan (Mustaji, 2013:1). Prinsip pemilihan media hendaknya didasarkan pada kebutuhan guru dan siswa serta materi pembelajaran yang akan dikaji dalam proses belajar mengajar agar pembelajaran berlangsung efektif dan tujuan pembelajaran dapat tercapai. Rumampuk (1988:19) mengemukakan prinsip-prinsip pemilihan media antara lain: (1) harus diketahui dengan jelas media dipilih untuk tujuan apa; (2) pemilihan media harus secara objektif dan didasarkan atas pertimbangan untuk meningkatkan efektifitas belajar siswa; (3) tidak ada satupun media yang dapat digunakan untuk mencapai semua tujuan, hendaknya melihat kelebihan dari suatu media yang akan digunakan untuk mencapai tujuan tertentu.

\section{Media Kit}

Menurut klasifikasinya, media kit merupakan media kategori media model padat. Lebih lanjut Sudjana (2011:156) mengemukakan kit termasuk dalam kategori media tiga dimensi yakni model padat (solid model). Media dengan model padat memperlihatkan bagian permukaan luar dari suatu objek dan dibuang bagian yang membingungkan ide utamanya dari bentuk, warna, dan susunannya.

Heinich (1982:174) juga mengemukakan kit multimedia adalah sekumpulan bahan ajar dari guru atau media pembelajaran yang melibatkan lebih dari satu jenis media yang sengaja dibuat untuk menyampaikan suatu materi pelajaran. "Multimedia kit should be designed to teach specific knowledge and skills. They should involve the student in the learning process as he or she handles and manipulates the resource materials". Untuk mengajarkan pengetahuan dan keterampilan khusus, guru hendaknya mendesain media berupa kit multimedia. Guru harus melibatkan siswa dalam proses pembelajaran karena guru yang mengorganisaikan dan memanipulasi materi ajar.

Dari beberapa penjelasan di atas dapat ditarik kesimpulan bahwa kit merupakan seperangkat peraga/ model yang memuat beberapa komponen/ alat/ bahan pembelajaran yang dirancang khusus dan dikemas dalam satu wadah (box) untuk memudahkan penyampaian pesan dan informasi oleh guru kepada siswa berkaitan dengan materi pelajaran.

\section{E. Pendekatan Saintifik}

Pendekatan saintifik diadopsi dari metode scientific yang dikenalkan sekitar akhir abad ke-19 merupakan upaya membangun pengetahuan melalui proses ilmiah yang memungkinkan siswa untuk cakap dalam berpikir kritis dan kreatif serta berkembangnya "sense of inquiry" (Alfred de Vito dalam Nursyamsuddin, 2013:5). Dalam hal ini yang dipentingkan adalah proses belajar, bukan hanya sekedar memperoleh sejumlah pengetahuan, keterampilan, dan sikap tetapi proses bagaimana pengetahuan, keterampilan, dan sikap diperoleh. Pada pendekatan saintifik mencakup penemuan makna (meaning), organisasi, dan struktur dari ide atau gagasan, sehingga secara bertahap siswa belajar bagaimana mengkoordinasikan dan melakukan tindakan-tindakan penelitian. Sehingga, melalui penemuan-penemuan pengetahuan yang didasarkan pada pengalaman belajar, hukum-hukum, prinsip-prinsip, dan generalisasi, akan memberikan peluang berkembangnya keterampilan berpikir tingkat tinggi pada siswa (Houston, 1988:208). Adapun langkah-langkah pembelajaran berbasis saintifik (Lampiran Permendikbud No 103 Tahun 2014 tentang Deskripsi Langkah Pembelajaran) antara lain mengamati, menanya, mengumpulkan informasi, mengolah informasi, dan mengkomunikasikan.

\section{F. Penguasaan Konsep}

Konsep diperoleh sebagai hasil dari serangkaian kegiatan-kegiatan yang dapat dijadikan sebagai stimulus bagi siswa dalam mengkonstruk sebuah pengetahuan baru. Konsep merupakan penyajian internal sekelompok stimulus, konsep tidak dapat diamati, dan konsep harus disimpulkan dari perilaku (Dahar, 2011:62). Dengan demikian, dapat dirumuskan bahwa konsep merupakan suatu buah pikiran yang abstrak atau abstraksi mental yang dimiliki seseorang diperoleh dari fakta, peristiwa, pengalaman, dan lain-lain yang mempunyai atribut sama dan mewakili satu kelas stimulus. Dari berbagai pengalaman yang dialami oleh manusia, konsep itu sendiri mengalami perkembangan yang memungkinkan terjadinya modifikasi atau perubahan konsep karena pengalaman yang dialami.

Anderson \& Krathwohl (2001:31) membuat kategori dan proses kognitif kemampuan manusia, yang merupakan revisi dari taksonomi Bloom, dan kawan-kawan adalah sebagai berikut.

1. Remember (mengingat), yaitu memanggil kembali suatu pengetahuan yang sudah terekam dalam memori.

2. Understand (memahami), seseorang telah mampu membangun definisi dari suatu pengetahuan dalam pembelajaran.

3. Apply (menerapkan), seseorang menerapkan pengetahuannya baik pada kondisi yang sama dengan yang diajarkan maupun pada kondisi baru. 
4. Analyse (analisa), antara lain membedakan, mengorganisasikan (kesesuaian dan keberfungsian suatu objek), mendekonstruksikan (menentukan sudut pandang suatu objek).

5. Evaluation (evaluasi), terdiri dari mengecek (mendeteksi apakah ada ketidaksesuaian suatu produk atau proses) dan mengkritisi (mengecek menggunakan kriteria eksternal.

6. Create (mencipta), mengenali unsur-unsur atau bagian kemudian menggabungkannya menjadi pola atau struktur baru. Kategori mencipta antara lain berhipotesis, merencanakan, menghasilkan.

\section{METODE PENELITIAN}

Penelitian ini merupakan penelitian pengembangan, dengan model ADDIE. Desain uji coba terbatas menggunakan one group pretest-posttest design dengan teknik analisis deskriptif kuantitatif dan deskriptif kualitatif. Subjek uji coba ini adalah siswa kelas VI SDN 3 Kedungwinangun, Kebumen, tahun pelajaran 2015/2016.

Adapun penelitian ini dikembangkan menggunakan pendekatan ADDIE (Analyse-Design-DevelopImplement-Evaluate).

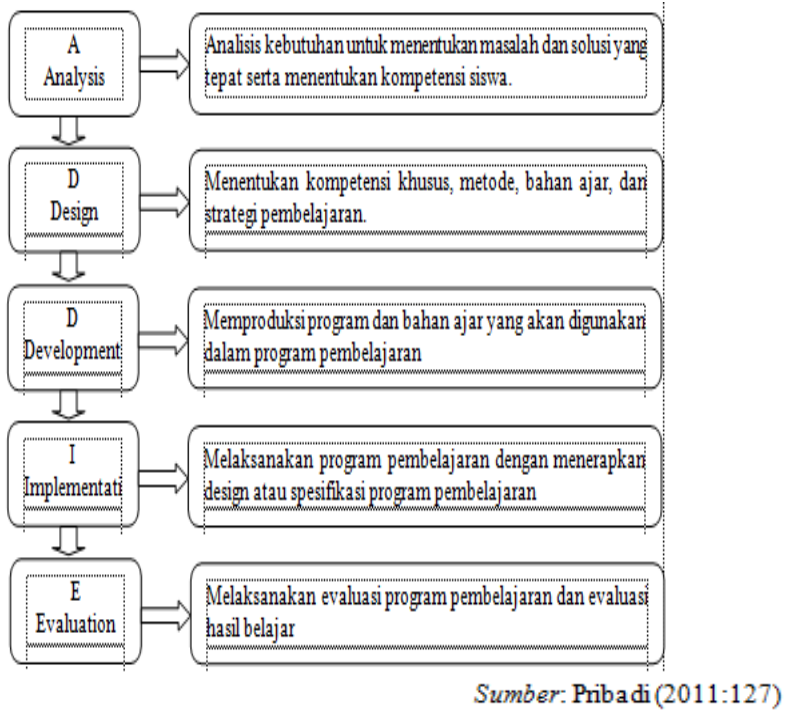

Gambar 3

Pengembangan dengan Menggunakan ADDIE

Desain penelitian ini adalah pre-experimental design tipe one group pretest-posttest. Desain penelitian one group pretest-posttest memiliki tujuan untuk membandingkan hasil sebelum diberi perlakuan dengan hasil setelah diberi perlakuan (Sugiyono, 2009:74). Desain ini dapat digambarkan sebagai berikut.
Keterangan:

$\mathrm{O}_{1}=$ nilai pretest (sebelum diberi perlakuan)

$\mathrm{O}_{2}=$ nilai posttest (setelah diberi perlakuan)

Sebelum diimplementasikan, perangkat terlebih dahulu diujicobakan guna mengetahui validitas, reliabilitas, gain skor, serta sensitivitas butir soal. Instrumen yang digunakan antara lain terdiri dari lembar vallidasi perangkat pembelajaran, angket keterbacaan, angket respon siswa, lembar hambatan dan keterlaksanaan RPP.

Data yang telah diperoleh kemudian dianalisis secara deskripsi kualitatif dan deskripsi kuantitatif. Adapun metode pengumpulan data yang digunakan antara lain validasi, observasi, tes, dan angket.

\section{HASIL DAN PEMBAHASAN}

\section{Kelayakan}

Berikut penilaian kelayakan perangkat pembelajaran ditunjukkan pada tabel berikut.

\section{Tabel 1.}

Kelayakan Perangkat

\begin{tabular}{ccccc}
\hline No. & Perangkat & Rerata Skor & Reliabilitas & Ket. \\
1 & RPP & V1 $=3,85$ & $98,68 \%$ & Baik \\
& & V2 $=3,75$ & & \\
2 & LKS & V1 $=4,00$ & $98,73 \%$ & Baik \\
& V2 $=3,90$ & & \\
\multirow{2}{*}{3} & \multirow{2}{*}{ BAS } & V1 $=3,91$ & $98,31 \%$ & Baik \\
& & V2 $=3,78$ & & \\
4 & Kit & V1 $=3,90$ & $98,70 \%$ & Baik \\
& & V2 $=3,80$ & & \\
5 & Tes & V1 $=3,99$ & $98,47 \%$ & Baik \\
\hline
\end{tabular}

Adapun tingkat keterbacaan BAS dan LKS masingmasing adalah sebesar $87,5 \%$ dan $86,09 \%$. Dari persentase mengenai tingkat keterbacaan BAS dan LKS menunjukkan bahwa pembaca berada pada tingkat independen (Rankin dan Kulhane dalam Kamidjan dalam Laksono, 2007:4.274.28) dan dapat dikatakan bahwa keterbacaan buku adalah baik.

\section{Kepraktisan}

Rata-rata penilaian dari dua pengamat terhadap pelaksanaan RPP pertemuan 1 sebesar 3,53 dengan realibilitas 97,02; pertemuan 2 sebesar 3,63 dengan realibilitas $100 \%$, dan pertemuan 3 sebesar 3,71 dengan realibilitas 99,19\%. Dengan demikian dapat dikatakan bahwa pembelajaran IPA berbasis saintifik yang menggunakan kit media IPA Tata Surya terlaksana dengan baik. Siswa berperan aktif dalam pembelajaran (student centered) dan guru mampu menjadi fasilitator siswa.

\section{$\mathbf{O}_{1} \times \mathbf{O}_{2}$}


Adapun data yang diperoleh mengenai aktivitas siswa adalah sebagai berikut.

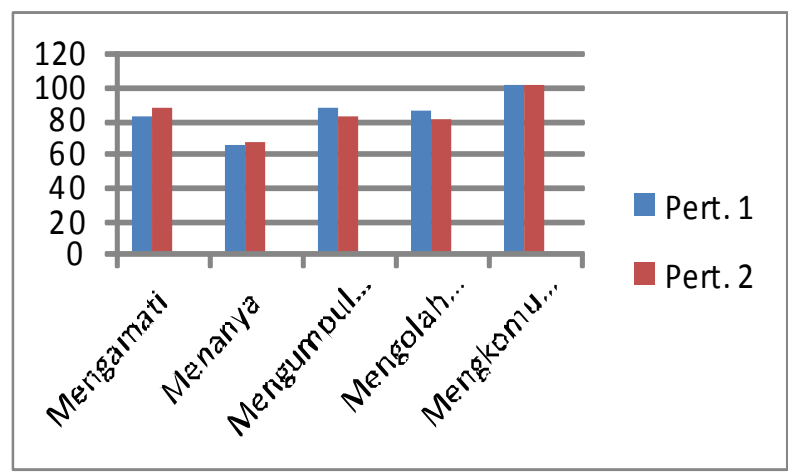

Diagram 1.

Aktivitas Siswa

Hambatan yang ditemui pada saat pembelajaran berlangsung secara umum adalah mengenai alokasi waktu yang belum optimal, serta pada penggunaan kit media karena masih tergolong baru sehingga siswa masih canggung pada saat belajar menggunakan kit media IPA.

\section{Keefektifan}

Berdasarkan data yang diperoleh mengenai keefektifan yang dicapai dari sisi respon siswa terhadap pembelajaran secara umum adalah positif. Persentase siswa yang memberikan respon positif adalah sebesar 82,9\%. Sedangkan persentase siswa yang memberikan respon negatif sebesar $17,1 \%$.

Berikut ini ditunjukkan data yang diperoleh mengenai respon siswa terhadap pembelajaran IPA berbasis saintifik yang menggunakan kit media.

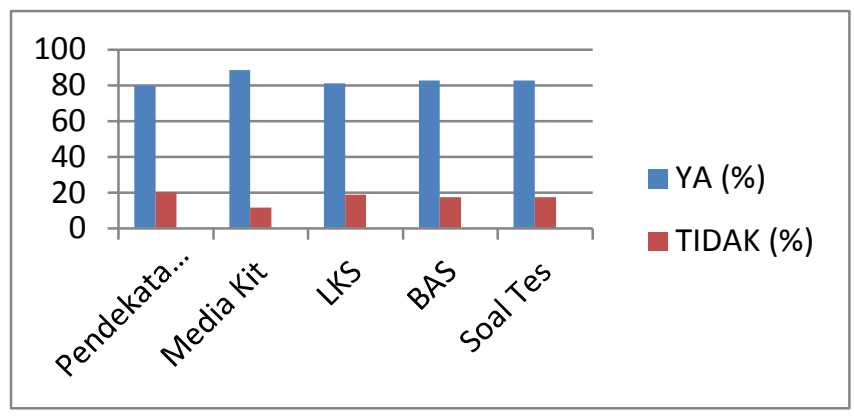

Diagram 2.

Respon Siswa

Keefektifan pembelajaran juga dilihat dari peningkatan penguasaan konsep siswa. Berikut data yang diperoleh mengenai hasil belajar siswa dan peningkatannya (gain skor). Pada hasil pretest nilai rata-rata 23 siswa hanya 1 siswa yang telah mengalami ketuntasan pada. Sedangkan hasil posttest menunjukkan rata-rata nilai dari
23 siswa adalah 82,61 dan seluruh siswa telah mencapai ketuntasan.

Peningkatan hasil belajar ini diukur dengan menggunakan perhitungan gain skor siswa terhadap hasil pretest dan posttest. Dari data yang diperoleh menunjukkan 9 orang siwa memiliki gain sedang dan 14 orang siswa memiliki gain tinggi dengan perolehan gain skor rata-rata dari 23 siswa adalah 0,7. Hal ini menunjukkan rata-rata gain skor yang diperoleh seluruh siswa tinggi. Dengan kata lain bahwa peningkatan penguasaan konsep siswa tinggi dan memiliki perbedaan yang signifikan antara sebelum dan sesudah diberi perlakuan karena memiliki gain skor $\geq$ 0,7 (Hake dalam Savinainen \& Scott, 2002).

\section{SIMPULAN DAN SARAN}

Berdasarkan analisis, pembahasan hasil, dan temuan penelitian, maka dapat disimpulkan bahwa pengembangan kit media pembelajaran IPA menggunakan model pengajaran berbasis saintifik untuk meningkatkan penguasaan konsep materi tata surya pada siswa kelas VI Sekolah Dasar telah memenuhi syarat kevalidan, kepraktisan, dan keefektifan sehingga layak digunakan dalam proses pembelajaran.

Adapun saran yang diajukan adalah sebagai berikut.

1. Hendaknya dilakukan penelitian lanjutan tentang penggunaan kit media pada pembelajaran berbasis saintifik untuk materi-materi yang lain

2. Berdasarkan hasil penelitian yang menyatakan bahwa kit media IPA berbasis saintifik layak, praktis, dan efektif, diharapkan dapat diterapkan pula di sekolahsekolah yang lain.

3. Diharapkan sekolah lebih memperhatikan tentang pentingnya sarana pembelajaran berupa media.

\section{DAFTAR PUSTAKA}

Anderson, Lorin W. \& Krathwol, David R. (2001). A Taxonomy for Learning, Teaching, and Assessing. A Revision of Bloom's Taxonomy of Educational Objectives. New York: Addison Wesley Longman, Inc.

Arends, Richard I. (2008). Learning to Teach Belajar untuk Mengajar. Edisi Ketujuh. New York: Mc. Graw-Hill Companies, Inc.

Dahar, Ratna Wilis. (2011). Teori-Teori Belajar dan Pembelajaran. Jakarta: Erlangga.

Dewantara, Ki Hajar. (1977). Pendidikan. Yogyakarta: Majelis Luhur Persatuan Taman Siswa. 
Fathurrohman, P. (2007). Strategi Belajar Melalui Penanaman Konsep Umum dan Konsep Islam. Bandung: PT Refika Aditama.

Heinich, Robert, Michael Molenda, \& James D. Russell. (1982). Instructional Media and The New Technologies of Instruction. Newyork: John Wiley \& Sons, Inc.

Houston, W.R., Cliff, R.T., Reiberg H.J. \& Wargen A.R. (1988). Touch The Future: Teach. New York: West Publishing Company.

Ibrahim, Muslimin, dkk. (2008). Model Pembelajaran Inovatif IPA melalui Pemaknaan. Surabaya: Unesa University Press.

Ibrahim, Muslimin, dkk. (2010). Dasar-Dasar Proses Belajar Mengajar. Surabaya: Unesa University Press.

Karsidi. (2007). Model Kurikulum Tingkat Satuan Pendidikan (KTSP). Solo: PT Tiga Serangkai Pustaka Mandiri.

Laksono, Kisyani. (2007). Membaca 2. Modul UT. Jakarta: Universitas Terbuka.

Mustaji. (2013). Media Pembelajaran. Surabaya: Unesa University Press.

Nagl, M. G., Obadovic, D. Z., \& Segedinac. (2012). Efectivitive Teaching of Physics and Scientific Method. TEM Journal, 2, Vol. 1, page 85-89.

Nusyamsuddin, dkk. (2013). Pembelajaran Berbasis Kompetensi dengan Pendekatan Saintifik. Jakarta: Kemendikbud RI.

Permendikbud. (2014). Peraturan Menteri Pendidikan dan Kebudayaan Republik Indonesia Nomor 103 Tahun 2014 tentang Pembelajaran pada Pendidikan Dasar dan Pendidikan Menengah. Jakarta: Departemen Menteri Pendidikan dan Kebudayaan Republik Indonesia.

Pribadi, Benny A. (2011). Model Desain Sistem Pembelajaran. Jakarta: Dian Rakyat.

Rohman, Muhammad. (2012). Kurikulum Berkarakter, Refleksi dan Proposal Solusi terhadap KBK dan KTSP. Jakarta: Prestasi Pustakarya.

Rumampuk, D.B. (1988). Media Instruksional IPS. Jakarta: Depdikbud.
Savinainen, A. \& Scott P. (2002). The Force Concept Inventory: A Tool for Monitoring Student Learning. Physic Education, 37 (1), page 45:52.

Slameto. (2010). Belajar dan Faktor-Faktor yang Memengaruhinya. Jakarta: Rineka Cipta.

Subiyanto. (1988). Pendidikan Ilmu Pengetahuan Alam. Jakarta: Departemen Pendidikan dan Kebudayaan.

Sudjana, Nana dan Ahmad Rivai. (2011). Media Pengajaran. Bandung: Sinar Baru Algesindo.

Sugiyono. (2009). Metode Penelitian Kuantitatif Kualitatif dan $R \&$ D. Bandung: Alfabeta. 